\title{
WHY TO GO FOR EARLY RETIREMENT? DETERMINANTS FOR EARLY EXIT FROM THE LABOUR MARKET: THE EVIDENCE FROM BULGARIA
}

\author{
Ekaterina MARKOVA \\ E-Mail: emarkova@bas.bg \\ Chief assistant professor \\ Institute of Philosophy and Sociology at the Bulgarian Academy of Sciences, \\ Sofia, Bulgaria

\section{Ekaterina TOSHEVA} \\ E-Mail: etosheva@unwe.bg \\ Associate Professor \\ University of National and World Economy, Department of Statistics and \\ Econometrics, Sofia, Bulgaria
}

\begin{abstract}
In line with the increase of retirement age and challenges toward longer and healthier working lives in Europe, this evidence-based research aims to enlighten determinants of early retirement in Bulgaria, which is the most rapidly ageing and economically deprived country in European Union. This cross-sectional analysis is based on Survey of Health Ageing and Retirement in Europe (SHARE: release 7.0). The early retirement plans for late career Bulgarians are significantly shaped by gender. Early retirement could be perceived as a source of guaranteed income and solution in case of unsecured employment, especially to those with bad health and low education.
\end{abstract}

Key words: early retirement, ageing, gender, Bulgaria, SHARE

\section{Introduction}

Population ageing requires sensitive and multilevel planning of the potential of the European societies to work better and longer, both at a national and panEuropean level. The comparative perspective of demographic development in Europe shapes policies and further research (Mick, 2015), but population ageing poses a serious challenge to policy makers and societies across Europe due to multidimensional country variations and societal specifics (EPRS, 2019). 
Bulgaria could be defined as an extreme case according to its demographic development, a rapidly ageing society, with high poverty rates and population ageing without living longer (Botev, 2012, pp. 69-79; Davoudia, 2010). The Bulgarian transition from planned to market economy in the 1990s has been described as an "economic disaster" (Minassian, 2007), reflected in full force the social-security system and labour market. After accession to the European Union (EU) in 2007, Bulgaria has been developing under the pressure of rapid population ageing and external migration. The share of Bulgarians aged $60+$ is $27.9 \%$, although life expectancy in Bulgaria is the lowest in the EU, at 75.0 years in 2018 (Eurostat, 2019a). The poverty risk in the EU for the total population is $21.8 \%$ compared to $32.8 \%$ in Bulgaria (Eurostat, 2018a; Eurostat $2019 \mathrm{~b})$. The proportion of ageing population (55+) falling into poverty risk or social exclusion, at $38.9 \%$, is considerably higher than the EU average of $20.5 \%$. Demographic trends in Bulgaria reveal a critically ageing population with a low life expectancy and a high poverty risk, which raises the question of whether the social systems might be able to respond adequately. The Bulgarian pension system dependency ratio is under great pressure (77.5-80.4 in the period 2009-2018) (NSI, 2018). The future needs of the Bulgarian labour market should also take into account the fact that the average duration of working life is relatively low 33.1 years, compared to 36.2 years for all EU members (Eurostat, 2020a). In line with the EU demographic response to ageing, Bulgaria started to continuously increase the retirement age. As of 2029 , men will be required to work until 65 years of age and women by 2037, compared to 64 years and 3 months for men and 61 years and 6 months for women in 2020. As a result of the retirement policy in Bulgaria, the employment rate of workers aged 55-64 rose rapidly from $44.6 \%$ in 2011 to $60.7 \%$ in 2018, compared to the EU average of $58.7 \%$ (Eurostat, 2020b). The share of working retirees increased by 27\% from 2015 to 2018 (NSSI, 2018). The short-term challenge for the Bulgarian social systems is how to strengthen late-career employment with qualified, healthy and motivated employees. Since 2018, Bulgaria has increased the retirement age in early retirement schemes, which were already limited to several groups of occupations with problematic working conditions. For instance, the retirement age for teachers used to be 58 years for women and 61 for men, but it was increased to 62 years for both genders in 2018 (NSSI, 2020).

The aim of this cross-national research is to identify determinants of the individual push and pull factors for early retirement plans within the perspective of gender differences (Kolberg, 1991, pp. 3-5; Scharn, 2018; de Preter, 2018, pp. 299-307; van den Berg, Elders, Burdorf, 2010b). What individual attitudes and life circumstances may lie beneath the plan to exit the labour market earlier? The phenomenon "early retirement plans" for late career Bulgarians is described and analysed from empirical evidence in the public release of the Survey of Health, Ageing and Retirement in Europe (SHARE), wave 7 (Börsch-Supan, 2019). The main analytical starting point is that in Bulgaria the early retirement plans are determined by gender, and by various individual and family and/or household factors with a country-specific 
Why to go for early retirement? Determinants for early exit from...

background. From a scientific point of view, it is important to investigate the attitudes towards early retirement, and the motives of late career Bulgarians within the current legislative framework that allows limited early retirement schemes, and constantly increases the retirement age. The impact of ageing on changes in the career development is not broadly studied in the countries in Eastern Europe, where, in the past decade, access to early retirement schemes has been limited, combined with increase in retirement age both for male and female. A phenomenon in the pension systems in Eastern Europe is the difference in the retirement age between men and women which is a remnant of the socialist regimes. The trend in the future, along with an increase in retirement age, is for these differences to be equalised.

\section{Theoretical and empirical considerations}

The cross-national perspective of early retirement domains in Bulgaria is important for a better understanding of the national specifics of ageing and its socio-economic impact. The country specifics should be taken into consideration in line with the comparative analyses because the domains and determinants of retirement timing vary across countries (Scharn, 2018). The country variations stress the EU cohesion policy (Dyba et al., 2018), as well as tension and policy challenges to the respected countries. The East-West European divide concerning preferred retirement timing is related to unfavourable working conditions, such as low job control and low wages, and variations with regard to retirement policies, such as gender variations in employment, career history and income (Dahl et al., 2003, pp. 179-198: Edge et al., 2017; König, 2017; De Tavernier, 2005). Retirement decision could be explained as a rational choice and balance between individual and family advantages and disadvantages of retirement (Wang, Shultz, 2010; Mortelmans, Vannieuwehhuyze, 2011), an adaptation process (Taylor, Cook, 1995) and career development stage (Post, Schneer and Reitman, 2013), as dependant on macro factors such as economic development, legislation, and retirement schemes, (de Preter et al., 2013; Reeuwijk et al., 2013) or, the perspective of human resources development and employers' influence on late-career decision (Mortelmans, Vannieuwehhuyze, 2011, pp. 13-22). On the macro level, when the socio-economic environment is favourable, the likelihood of early retirement is much lower than in cases of high unemployment and economic recession. On the micro level, the desire for early retirement is often associated to a lesser extent with a rational choice than with a lack of employment opportunities, (Badun, Smolic, 2017, pp. 671-690; Herbertsson, 2001) though bad health is also a factor (Mortelmans 2011; Badun, Smolic, 2017; de Wind 2013; van den Berg et al., 2010a). In Eastern Europe, the preference to retire early demonstrates a tendency to be perceived as a "habit" (De Tavernier, 2005). Higher education is a pull factor in retirement planning, contributing to a lesser likelihood of early retirement. Less educated persons are more often in a state of unemployment, or in low quality jobs transforming the early retirement into a desirable outcome. However, the low-educated are often forced to delay the transition from employment to retirement due to lack of 
money (Breij et all., 2019; Badu, Smolic, 2017, pp. 671-690). The social networks, partnership, presence of children and grandchildren, or elderly, or care for some dependent member of the household could also be significant determinants for early retirement (Hochman, Lewin-Epstein, 2013, pp. 29-47). Gender differences in Bulgaria could be expected to influence the determinants of retirement timing due to the gender variations in labour income, retirement age, and women's role as mothers and providers of care within the home (Ciccia, Bleijenbergh, 2014). The scientific interest in early retirement plans in late career Bulgarians is provoked by the discrepancy between the institutional and economic limitations and the individual tendencies towards early exit from the labour market, as well as the lack of empirical data and analyses of the late career Bulgarians.

\section{Methods}

Data

Bulgaria joined the seventh wave of Survey of Health, Ageing and Retirement in Europe (SHARE) for the first time in 2017. The SHARE wave 7 publicly released data is representative, cross-national for the non-institutionalised Bulgarians aged 50 or more, and includes extensive information on socioeconomic indicators, physical, cognitive and mental health, family networks and life history (Börsch-Supan, 2019). The sample of SHARE wave 7 in Bulgaria covers 2006 individual interviews from 1348 households (Bergman et al., 2019). The subsample explored in this study covers persons aged 50+ who are employed or self-employed, including those working for a family business, and who are eligible to provide answers about their early retirement plans. The current analysis is based on calibrated individual weights (Bergman et al., 2018) to overcome bias in the sample design and non-response (Korn, 1995).

\section{Outcome}

This study analysed the likelihood of voluntary early retirement for late career Bulgarians, aged 50+. The eligible SHARE respondents were those who reported active employment at the moment of the survey.

Determinants:

Considering the above theory concerning retirement timing and the content of wave 7 of the Survey of Health, Ageing and Retirement in Europe (SHARE), a cross-national model with three domains for the late career Bulgarians, aged 50+, have been explored: 1) Demographic determinants: education, gender, family status; 2) Health determinant: self-perceived health; 3) Socio-economic determinants: quality of life, according to the CASP index, and household economic situation. The examined subsample was controlled by employment status; all participants were in active employment or self-employment. The research matrix was formed by individual data about age $50+$, in three age cohorts, up to 54, 55-59, and 60+; gender, level of education, primary or lower secondary, secondary or post-secondary, non-tertiary, tertiary; and family status, with or without a partner/spouse. The general health was measured with 'self-perceived health' aggregated in three categories (poor or fair, good, very 
good or excellent). The quality of life was measured by a 12-item CASP index (Borrat-Bensson et al., 2015). The CASP scale ranged from 12 to 48 where a higher score meant higher quality of life. The median CASP score for the target population was 36 . The household economic situation, i.e. 'Is the household able to make ends meet', was constructed in four categories, with great difficulty, with some difficulty, fairly easily, or easily. The income variable had $30 \%$ missing information, so it was included in the descriptive analysis, but it was excluded from the logistic models.

\section{Methods}

A multiple logistic model was used to estimate the odds ratio (proportion between positive and negative answers) of early retirement depending on the following determinants: gender, education, economic situation, marital status, quality of life and general health.

According to theory and previous research, the drivers for early retirement differ by gender, so the logistic regression models were additionally estimated for men and women separately.

$$
\begin{aligned}
& \frac{\pi}{1-\pi}=\exp \left(b_{0}+b_{1} X_{1}+b_{2} X_{2}+\ldots .+b_{k} X_{k}\right) \\
& \log \left(\frac{\pi}{1-\pi}\right)=b_{0}+b_{1} X_{1}+b_{2} X_{2}+\ldots+b_{k} X_{k}
\end{aligned}
$$

\section{Analysis}

A subsample of 506 of Bulgarians aged $50+$ or $42.40 \%$ of the total number of respondents, declared an intention to retire early. Differences within this subgroup by the above listed determinants as well as descriptive statistics (unweighted and weighted data with calibrated cross-national weights) are presented in Table 1.

The Bulgarian SHARE data confirm, in line with the previous research and theory, that mostly women, persons living with a partner and less educated persons express a desire to retire early from their main job. One of the most important factors for retirement timing for Bulgarians seems to be general health, with interesting gender variation. The largest variations observed in intentions to retire early are within the self-perceived health categories. Two thirds of the persons with poor or fair health express intentions to retire early, compared to one third of the persons with very good or excellent health. A higher quality of life leads to a longer working life, although the CASP index is not very sensitive, which is most probably due to contradictory influences of its components. The higher quality of life could be related to a slight decrease in the likelihood of early retirement as $48 \%$ of the respondents with CASP below or equal to the median declared a desire to retire early, compared to $38 \%$ with CASP above the median. (The median was 36 for the studied subpopulation.) Education seems to be a very influential factor for early 
retirement. More than a half, 53\%, of the Bulgarians with primary of lower secondary education compared to $29 \%$ of the Bulgarians with tertiary education express intentions to retire earlier. 
Why to go for early retirement? Determinants for early exit from...

Table 1. Descriptive statistics for persons looking for early retirement from (main) job

\begin{tabular}{|c|c|c|c|}
\hline & \multicolumn{2}{|c|}{ Unweighted (Yes) } & $\begin{array}{l}\text { Weighted (Yes) } \\
\%\end{array}$ \\
\hline Total & 213 & $42.40 \%$ & $40.70 \%$ \\
\hline \multicolumn{4}{|l|}{ Gender } \\
\hline Male & 97 & $39.75 \%$ & $38.71 \%$ \\
\hline Female & 116 & $44.96 \%$ & $42.72 \%$ \\
\hline \multicolumn{4}{|l|}{ Level of Education } \\
\hline Primary or lower secondary & 34 & $53.13 \%$ & $52.93 \%$ \\
\hline Secondary education or post-secondary non-tertiary education & 133 & $44.93 \%$ & $43.69 \%$ \\
\hline Tertiary education & 44 & $31.88 \%$ & $28.63 \%$ \\
\hline \multicolumn{4}{|l|}{ Marital Status } \\
\hline Living with spouse & 167 & $44.30 \%$ & $43.49 \%$ \\
\hline Living without spouse & 46 & $36.80 \%$ & $35.25 \%$ \\
\hline \multicolumn{4}{|l|}{ Age at the interview } \\
\hline Up to 54 & 75 & $42.37 \%$ & $41.97 \%$ \\
\hline From 55 to 59 & 78 & $41.05 \%$ & $37.95 \%$ \\
\hline 60 andmore & 60 & $44.44 \%$ & $42.38 \%$ \\
\hline \multicolumn{4}{|l|}{ Is household able to make ends meet? } \\
\hline With great difficulty & 32 & $54.2 \%$ & $50.84 \%$ \\
\hline With some difficulty & 133 & $44.2 \%$ & $42.73 \%$ \\
\hline Fairly easily & 36 & $33.0 \%$ & $30.97 \%$ \\
\hline Easily & 12 & $36.4 \%$ & $31.79 \%$ \\
\hline \multicolumn{4}{|l|}{ Self-perceived health } \\
\hline Poor or fair & 38 & $62.30 \%$ & $64.07 \%$ \\
\hline Good & 90 & $47.62 \%$ & $47.22 \%$ \\
\hline Very Good or Excellent & 85 & $33.73 \%$ & $31.63 \%$ \\
\hline \multicolumn{4}{|l|}{ CASP - quality of life index } \\
\hline Up to 36 & 110 & $47.83 \%$ & $44.79 \%$ \\
\hline 37 andmore & 102 & $37.78 \%$ & $37.06 \%$ \\
\hline \multicolumn{4}{|l|}{$\begin{array}{l}\text { Total income received by all household members an average } \\
\text { month last year* }\end{array}$} \\
\hline Up to 500 BGN** & 22 & $51.16 \%$ & $53.62 \%$ \\
\hline More than $500-750 \mathrm{BGN}$ & 25 & $44.64 \%$ & $40.44 \%$ \\
\hline More than $750-1000 \mathrm{BGN}$ & 33 & $45.83 \%$ & $40.75 \%$ \\
\hline More than $1000-1500 \mathrm{BGN}$ & 29 & $34.94 \%$ & $30.23 \%$ \\
\hline More than $1500 \mathrm{BGN}$ & 10 & $23.26 \%$ & $27.42 \%$ \\
\hline
\end{tabular}

"Missing data $30.2 \%$

*1 EURO is equal to $1.99583 \mathrm{BGN}$ 
The existence of a spouse or partner also leads to differences, with $44 \%$ of the persons with a spouse/partner being interested in exiting the labour market earlier, compared to $35 \%$ of the persons living alone. Economic household status demonstrates a logical influence. Living in households with economic difficulties increases the proportion of persons who want to retire early, from $42 \%$ to $31 \%$. The same tendency is confirmed by income, with more than a half, 54\% of Bulgarians living in households with the lowest income of up to 250 EUR, being likely to retire early, compared to $27 \%$ of Bulgarians from households with the highest income of 750 and more EUR.

The results of descriptive statistics are in line with the multiple logistic regression models (Table 2). One of the highest gender variations is observed in the education determinant. Education plays a larger role in retirement timing for men than it does for women. The probability of early retirement is about 3.8 times higher for low-educated men compared to men with tertiary education. Women with primary or lower secondary education are 2.4 times more likely to be willing to retire early. Early retirement is preferred 1.1 times more often by women with secondary education that by those with tertiary education. As expected, living with a partner affects intentions to retire early. Women living with a partner/spouse are 1.7 times more likely to retire early than women living alone. Men demonstrate the opposite tendency - the odds ratio of early retirement is 0.93 when living with a partner/spouse. The age variable is included in the model as a covariate. The increase of age by 1 year does not change the odds ratio (0.99). The reason might be that the subsample of interest includes economically active individuals where the highest age cohorts are still working.

Clear gender differences are observed concerning the economic determinant. As expected, the economic status of the household affects more men than women concerning early retirement. The general model of men and women indicates that the probability of early retirement is 1.4-1.5 times higher for people with economic difficulties. Self-perceived health has a greater impact on early retirement among men. In general, late career Bulgarians with poor or fair health have 3.2 ( 4.8 for men, 2.5 for women) times higher odd ratio of early retirement compared to those with good or excellent health. The ones with good self-perceived health have 1.8 ( 2.1 men, 1.4 women) higher odd ratio of early retirement compared to those with very good or excellent self-perceived health. The CASP index is included in the model as covariate. When the CASP index increases by 1 , the odds ratio of early retirement is 0.98 . The CASP index was previously tested as a group variable, but the results were ambiguous, which was most probably due to the contradictory influence of its components for men and women. 
Why to go for early retirement? Determinants for early exit from...

Table 2. Multiple logistic regression models

\begin{tabular}{|c|c|c|c|c|c|c|c|c|c|c|}
\hline \multicolumn{2}{|c|}{ factors (categories) } & $\mathrm{B}$ & Sig. & $\operatorname{Exp}(B)$ & $\mathrm{B}$ & Sig. & $\operatorname{Exp}(B)$ & $\mathrm{B}$ & Sig. & $\operatorname{Exp}(B)$ \\
\hline \multirow{3}{*}{ baseline } & Gender & \multirow[b]{3}{*}{$0.18 * *$} & \multirow[b]{3}{*}{0.00} & \multirow[b]{3}{*}{1.20} & \multirow{3}{*}{\multicolumn{3}{|c|}{ Male }} & \multirow{3}{*}{\multicolumn{2}{|c|}{ Female }} & \\
\hline & Male & & & & & & & & & \\
\hline & Female** & & & & & & & & & \\
\hline \multicolumn{11}{|c|}{ Marital Status } \\
\hline \multirow[t]{2}{*}{ baseline } & $\begin{array}{l}\text { living without } \\
\text { spouse }\end{array}$ & & & & & & & & & \\
\hline & $\begin{array}{l}\text { living with } \\
\text { spouse }\end{array}$ & $0.32 * *$ & 0.00 & 1.37 & $-0.07 * *$ & 0.00 & .93 & $0.55 * *$ & 0.00 & 1.73 \\
\hline \multicolumn{11}{|c|}{ Level of Education } \\
\hline \multirow[t]{4}{*}{ baseline } & Tertiary & & & & & & & & & \\
\hline & $\begin{array}{c}\text { primary or lower } \\
\text { secondary }\end{array}$ & $0.95 * *$ & 0.00 & 2.58 & $1.33 * *$ & 0.00 & 3.78 & $0.89 * *$ & 0.00 & 2.43 \\
\hline & $\begin{array}{c}\text { secondary } \\
\text { education or }\end{array}$ & & & & & & & & & \\
\hline & $\begin{array}{c}\text { post-secondary } \\
\text { non-tertiary } \\
\text { education }\end{array}$ & $0.63 * *$ & 0.00 & 1.87 & $1.34^{* *}$ & 0.00 & 3.83 & $0.08 * *$ & 0.00 & 1.09 \\
\hline \multicolumn{11}{|c|}{ Age } \\
\hline & & $-0.01 * *$ & 0.00 & 0.99 & $0.01^{* *}$ & 0.00 & 1.01 & $-0.04^{* *}$ & 0.00 & 0.96 \\
\hline \multicolumn{11}{|c|}{ Self-perceived health } \\
\hline \multirow[t]{3}{*}{ baseline } & $\begin{array}{c}\text { very good or } \\
\text { excellent }\end{array}$ & & & & & & & & & \\
\hline & poor or fair & $1.17^{* *}$ & 0.00 & 3.21 & $1.57^{* *}$ & 0.00 & 4.81 & $0.93 * *$ & 0.00 & 2.53 \\
\hline & good & $0.59 * *$ & 0.00 & 1.80 & $0.76 * *$ & 0.00 & 2.13 & $0.39 * *$ & 0.00 & 1.47 \\
\hline \multicolumn{11}{|c|}{ Is household able to make ends meet } \\
\hline \multirow[t]{4}{*}{ baseline } & Easily & & & & & & & & & \\
\hline & $\begin{array}{l}\text { with great } \\
\text { difficulty }\end{array}$ & $0.40^{* * *}$ & 0.00 & 1.49 & $0.61^{* *}$ & 0.00 & 1.83 & $-0.04^{*}$ & 0.06 & 0.96 \\
\hline & $\begin{array}{l}\text { with some } \\
\text { difficulty }\end{array}$ & $0.35 * *$ & 0.00 & 1.42 & $0.55^{* *}$ & 0.00 & 1.74 & $0.26 * *$ & 0.00 & 1.29 \\
\hline & fairly easily & $-0.20 * *$ & 0.04 & 0.98 & $0.18 * *$ & 0.00 & 1.19 & $-0.19 * *$ & 0.00 & 0.83 \\
\hline \multicolumn{11}{|c|}{ CASP index } \\
\hline & & $-0.02 * *$ & 0.00 & 0.98 & $-0.02 * *$ & 0.00 & .98 & $-0.04 * *$ & 0.00 & 0.96 \\
\hline & Constant & $-0.50 * *$ & 0.00 & 0.61 & $-2.35 * *$ & 0.00 & .10 & $2.42 * *$ & 0.00 & 11.23 \\
\hline
\end{tabular}

${ }^{*} \mathrm{p}<0.10 ;{ }^{* *} \mathrm{p}<0.05$

\section{Determinants}

The cross-national descriptive and regression models explore some distinction between push and pull factors on an individual or a family level (Table 3). Gender concerns the early retirement plans, acting as a pull factor for women living alone. Poor or bad health is a pull factor, along with financial difficulties and low education. 
Table 3. Push and pull determinants of early retirement for 50+ Bulgarians employed or self-employed

\begin{tabular}{|l|c|c|}
\hline Bulgaria & Individual level & Family and household level \\
\hline Push factors & Gender - female & Living with partner (female) \\
\cline { 2 - 3 } & Primary or lower secondary & Financial difficulties \\
\cline { 2 - 3 } & Poor or fair health & \\
\hline Pull Factors & $\begin{array}{c}\text { Gender - male } \\
\text { Secondary or tertiary } \\
\text { education }\end{array}$ & Living without economic \\
& $\begin{array}{c}\text { difficulties } \\
\end{array}$ & Very good or excellent \\
& health & Female, living alone \\
\cline { 2 - 3 } & \multicolumn{2}{|c}{} \\
\hline
\end{tabular}

\section{Results and discussion}

Women in Bulgaria are in an unfavourable position on the labour market due to their lower retirement age and gender pay gap (Eurostat 2018b). The social role of Bulgarian women as mothers and caregivers shapes their tendency to retire early when not living alone. As breadwinners in the Bulgarian family, men are more sensitive than women to poor or fair health, and express a desire for early retirement in such cases. Grandparenthood as a retirement factor is also valid not only for Bulgaria (Feldman, Beehr, 2011). The SHARE, wave 7 Bulgarian data does not include information about grandparenthood or intentions to work after retirement, but it could be expected that care of grandchildren would be one additional push factor for early retirement. Although women tend to receive lower wages and experience career disadvantages because of the lower retirement age, they should presumably have more motives to retire later. The women would plan to work longer in order to receive higher pensions, but this is not the case in Bulgaria. Caring for children, grandchildren, and other dependant family members is often a prerequisite for early retirement. Retirement timing also depends on having a partner or spouse (Dahl at al., 2003). Single Bulgarian men are more likely to retire earlier. The opposite trend is observed in single women as they are less likely to retire early. The current data analysis also corresponds with the conclusion that poor health of men has a strong influence on their early retirement plans (Clarke et al., 2012). The presence of long-term health problems is associated with lower probability of working full time after 62 years for men, while for women in Bulgaria the presence of chronic diseases cannot be confirmed as factor for early retirement.

The early retirement may be desired by the late career Bulgarians because of a relatively low, but secure source of income guaranteed by the state pension system. It is used as a solution to escape from unemployment or job insecurity on the labour market, especially when 50+ Bulgarians have low education and 
Why to go for early retirement? Determinants for early exit from...

low income combined with fair health. A higher level of education usually leads to better chances for employment and this is also observed in the SHARE data. Late career Bulgarians with a primary education are more likely to opt for early retirement than to look for low-quality jobs or be unemployed.

The aggregated CASP index as a determinant for early retirement is not as sensitive as previously expected (Hyde, M. at al., 2003). The preliminary research indicates that the CASP forming components have different strengths to determine early retirement plans, as well as contradictory tendencies for men and women. For instance, control and self-realisation have greater influence than all four CASP components. Components related to economic independence and especially shortage of money affect more men than women. The level of education is involved in such factors as unemployment, job insecurity, low quality of work and life, vulnerability and poverty; all those factors and their impact on retirement timing in Bulgaria will be further investigated within the next SHARE wave.

Workforce scarcity in Bulgaria could be overcome with flexible employment schemes, especially targeted to low-qualified late career Bulgarians with problematic health status. Low-educated and low-qualified persons need to be encouraged to remain in the labour market instead of retiring early. The age of the actively employed is not a factor for their early retirement plans.

The in-depth analysis of the reasons why, if one has the opportunity, one who is late-career employed would like to retire as soon as possible is of particular importance for both science and policy. In EU research and public policy, little space is devoted to research on determinants of retirement timing in crossnational perspective (Wojciech et al., 2018), especially on the individual motives and characteristics of late-career persons, a highly heterogeneous group of employees. The early retirement plans are made not just by people with low education, poor health, and low economic status. The public employment policies should be flexible and address the gender equality. In countries like Bulgaria, where women combine different social roles, but family care is mainly dependent upon them, the family status could be an important factor for planning the transition from employment to retirement. However, though early retirement is highly influenced by poor health, gender is an important factor for retirement timing in Bulgaria.

\section{Acknowledgment:}

This paper uses data from SHARE Wave 7 (DOIs: 10.6103/SHARE.w7.700), see Börsch-Supan et al. (2013) for methodological details. The SHARE data collection has been funded by the European Commission through FP5 (QLK6CT-2001-00360), FP6 (SHARE-I3: RII-CT-2006-062193, COMPARE: CIT5CT-2005-028857, SHARELIFE: CIT4-CT-2006-028812), FP7 (SHAREPREP: GA N²11909, SHARE-LEAP: GA N²27822, SHARE M4: GA $\mathrm{N}^{\circ}$ 261982) and Horizon 2020 (SHARE-DEV3: GA N676536, SERISS: GA $\mathrm{N}^{\circ} 654221$ ) and by DG Employment, Social Affairs \& Inclusion. Additional funding by the German Ministry of Education and Research, the Max Planck Society for the Advancement of Science, the U.S. National Institute on Aging 
(U01_AG09740-13S2, P01_AG005842, P01_AG08291, P30_AG12815, R21_AG025169, Y1-AG-4553-01, IAG_BSR06-11, OGHA_04-064, HHSN271201300071C) and by various national funding sources is gratefully acknowledged (see www.share-project.org).

Declarations

Funding: This study was funded by University of National and World Economy, Sofia, Bulgaria, Research Project НИД-НИ 08/18

Conflict of Interest: The authors declare that they have no conflict of interest.

\section{References:}

Bađun M., Smolić Š. (2018). Predictors of Early Retirement Intentions in Croatia. Društvena istraživanja, 27 (4), 671-690. doi:https://doi.org/10.5559/di.27.4.05

Bergmann M., Scherpenzeel A., Börsch-Supan A. (eds.) (2019). SHARE Wave 7 Methodology: Panel Innovations and Life Histories. Munich: MEA, Max Planck Institute for Social Law and Social Policy.

Retrieved from http://www.shareproject.org/fileadmin/pdf_documentation/MFRB_Wave7/SHARE_M ethodenband_A4_WEB.pdf Accessed on: 22.09.2020

Borrat-Besson C., Ryser V. A., Gonçalves J. (2015). An evaluation of the CASP-12 scale used in the Survey of Ageing and Retirement in Europe (SHARE) to measure Quality of Life among people aged 50+. Working paper 2015-4 (FORS Working Paper Series, Lausanne: FORS). Retrieved from:

https://forscenter.ch/wp-content/uploads/2018/07/fors_wps_2015-

04_borrat-besson.pdf Accessed on: 22.09.2020

Börsch-Supan A. (2019). Survey of Health, Ageing and Retirement in Europe (SHARE) Wave 1. Release version: 7.0.0. SHARE-ERIC. Data set. doi:10.6103/SHARE.w1.710

Börsch-Supan A., Brandt M., Hunkler C., Kneip T., Korbmacher J., Malter F., Schaan B., Stuck S., Zuber S. (2013). Data Resource Profile: The Survey of Health, Ageing and Retirement in Europe (SHARE). International Journal of Epidemiology. 992-1001. doi:https://doi.org/10.1093/ije/dyt088

Botev N. (2012). Population ageing in Central and Eastern Europe and its demographic and social context. European Journal of Ageing, 9, 6979. doi:10.1007/s10433-012-0217-9

Ciccia R., Bleijenbergh I. (2014). After the Male Breadwinner Model? Childcare Services and the Division of Labor in European Countries. Social Politics, 21, 1, 50-79. doi:10.1093/sp/jxu002 
Clarke P., Marshall V.W., Weir D. (2012). Unexpected Retirement from Full Time Work after Age 62: Consequences for Life Satisfaction in older Americans. European Journal of Ageing, 9, 3, 207-219. doi:10.1007/s10433-012-0229-5

Dahl S-Å., Nilsen Ø. A., Vaage K. (2003). Gender Differences in Early Retirement Behaviour. European Sociological Review 19, 2. Retrieved from: http://ftp.iza.org/dp522.pdf Accessed on 22.09.2020

Davoudia S., Wishardtb M., Strangeb I. (2010). The ageing of Europe: Demographic scenarios of Europe's futures. Futures 42, 8, 794-803. doi:https://doi.org/10.1016/j.futures.2010.04.011

de Breij S., Huisman M., Deeg D. J. H. (2019). Educational differences in macro-level determinants of early exit from paid work: a multilevel analysis of 14 European countries. European Journal of Ageing, 1, 11, 217-227. doi:https://doi.org/10.1007/s10433-019-00538-6

De Preter H., Van Looy D., Mortelmans D. (2013). Individual and institutional push and pull factors as predictors of retirement timing in Europe: a multilevel analysis. Journal of Aging Studies, 27, 4, 299-307. doi:10.1016/j.jaging.2013.06.003

De Tavernier W., Naegele L., Holman D., Hess M. (2019). Delaying Retirement. In Gu D., Dupre M. (eds), Encyclopedia of Gerontology and Population Aging. Springer, Cham

de Wind A., Geuskens G. A., Reeuwijk K. G. et al (2013). Pathways through which health influences early retirement: a qualitative study. BMC Public Health, 13, 292. doi:https://doi.org/10.1186/1471-2458-13-292

Dyba, W., Loewen, B., Looga, J., Zdrazil, P. (2018). Regional Development in Central-Eastern European Countries at the Beginning of the 21st Century: Path Dependence and Effects of EU Cohesion Policy. Quaestiones Geographicae, 37, 2, 77-92. doi:https://doi.org/10.2478/quageo-2018-0017

Edge C. E., Cooper A. M., Coffey M. (2017). Barriers and facilitators to extended working lives in Europe: a gender focus. Public Health Reviews, 38, 2. doi:10.1186/s40985-017-0053-8

Edward L., Korn E. L., Graubard B. I. (1995). Examples of Differing Weighted and Unweighted Estimates from a Sample Survey. The American Statistician, 49, 3, 291-295. doi:10.1080/00031305.1995.10476167

EPRS (2019), Demographic outlook for the European Union 2019. doi:10.2861/061378 Retrieved from https://www.europarl.europa.eu/RegData/etudes/IDAN/2019/637955/ EPRS_IDA(2019)637955_EN.pdf Accessed on 22.09.2020

Eurostat (2018a) People at risk of poverty or social exclusion, Retrieved from https://ec.europa.eu/eurostat/databrowser/view/t2020_50/default/table ?lang=en Accessed on 22.09.2020

Eurostat (2018b) Gender pay gap. Retrieved from https://ec.europa.eu/eurostat/tgm/table.do?tab=table\&init=1\&languag $\mathrm{e}=\mathrm{en} \& \mathrm{pcode}=\mathrm{sdg} \_05 \_20 \&$ plugin $=1$ Accessed on 22.09.2020 
Eurostat (2019a) Life expectancy at birth by sex. Retrieved from https://ec.europa.eu/eurostat/databrowser/view/sdg_03_10/default/tabl e?lang=en Accessed on 22.09.2020

Eurostat (2019b) People at risk of poverty or social exclusion. Retrieved from https://ec.europa.eu/eurostat/databrowser/view/t2020_50/default/table ?lang=en Accessed on 22.09.2020

Eurostat (2020a) Duration of working life - annual data. Retrieved from https://appsso.eurostat.ec.europa.eu/nui/show.do?dataset=lfsi_dwl_a \&lang=en Accessed on 22.09.2020

Eurostat (2020b) Employment rate by age. Retrieved from https://ec.europa.eu/eurostat/databrowser/view/tepsr_wc110/default/ta ble?lang=en Accessed on 22.09.2020

Feldman D. C., Beehr T. A. (2011). A Three-Phase Model of Retirement Decision Making. American Psychologist, 66, 3, 193-203. doi: $10.1037 / \mathrm{a} 0022153$

Herbertsson T. T. (2001). The economics of early retirement. Institute of economic studies, Working paper series. Reykjavik

Hochman O., Lewin-Epstein N. (2013). Determinants of early retirement preferences in Europe: The role of grandparenthood. International Journal of Comparative Sociology, 54, 1, 29-47. doi: $10.1177 / 0020715213480977$

Kolberg J. E., Esping-Andersen G. (1991). Welfare States and Employment Regimes. International Journal of Sociology, 21, 1

König, S. (2017). Career histories as determinants of gendered retirement timing in the Danish and Swedish pension systems. Eur J Ageing, 14, 397-406. doi: https://doi.org/10.1007/s10433-017-0424-5

Minassian, G (1998). The road to economic disaster in Bulgaria. Europe-Asia Studies, 50, 2, 331-349. doi:10.1080/09668139808412538

Mortelmans D., Vannieuwenhuyze J. T. (2013). The age-dependent influence of self-reported health and job characteristics on retirement. International journal of public health, 58, 1, 13-22. doi:10.1007/s00038-012-0411-8

Myck M. (2015). Living longer, working longer: the need for a comprehensive approach to labour market reform in response to demographic changes. European Journal of Ageing, 12, 3-5. doi: https://doi.org/10.1007/s10433-014-0332-x

National Social Security Institute (2020) Pensions. Retrieved from https://www.noi.bg/en/pensions/grantpensions/1854-posv13 Accessed 22.09.2020

National Social Security Institute (NSSI) (2018). Demography, economy and social security. Retrieved from https://nssi.bg/images/bg/about/statisticsandanalysis/statistics/pokazat eli/Demografia_2018.pdf Accessed 22.09.2020

Post C., Schneer J. A., Reitman F., ogilvie, d. t. (2013). Pathways to Retirement: A Career Stage Analysis of Retirement Age Expectations. Human Relations, 66, 1, 87-112. doi:10.1177/0018726712465657 
Scharn M., Sewdas R., Boot C., Huisman M., Lindeboom M., van der Beek A. J. (2018). Domains and determinants of retirement timing: A systematic review of longitudinal studies. BMC public health. 18, 1083. doi: https://doi.org/10.1186/s12889-018-5983-7

Taylor M. A., Cook K. (1995). Adaptation to retirement: Role changes and psychological resources. Career Development Quarterly, 44, 1, 67-82. doi: 10.1002/j.2161-0045.1995.tb00530.x

UN (2002). Political Declaration and Madrid Plan of Action on Ageing. New York, United Nations

van den Berg G. J., Deeg D. J. H., Lindeboom M., Portrait F. (2010). The Role of Early-Life Conditions in the Cognitive Decline due to Adverse Events Later in Life. The Economic Journal, 120, F411-F428. doi: https://doi.org/10.1111/j.1468-0297.2010.02396.X

van den Berg T. I. J., Elders L., Leo A. M., Burdorf A. (2010). Influence of Health and Work on Early Retirement. Journal of occupational and environmental medicine, 52, 6, 576-583. doi: https://doi.org/10.1097/JOM.0b013e3181de8133

von dem Knesebeck O., Hyde M., Higgs P., Kupfer A., Siegrist J. (2005). Quality of Life and Well-Being. In: Börsch-Supan, A. et al. (Eds) (2005). Health, ageing and retirement in Europe - First results from the Survey of Health, Ageing and Retirement in Europe (pp. 199-203). Mannheim: Mannheim Research Institute for the Economics of Aging (MEA)

Wang M., Shultz K. S. (2010). Employee Retirement: A Review and Recommendations for Future Investigation. Journal of Management, 36, 1, 172-206. doi: 10.1177/0149206309347957

Wojciech H., Kiełczewska A., Lewandowski P., Magda I. (2018). Job retention among older workers in Central and Eastern Europe. Baltic Journal of Economics, $18, \quad 2, \quad 69-94 . \quad$ doi: https://doi.org/10.1080/1406099X.2018.1514562 
